\title{
Identification of nitrate source using isotopic and geochemical data in the lower reaches of the Yellow River irrigation district (China)
}

\author{
Wenjia Wang ${ }^{1,2,3} \cdot$ Xianfang Song $^{1} \cdot$ Ying Ma $^{1}$
}

Received: 13 October 2015/ Accepted: 6 May 2016/Published online: 26 May 2016

(C) Springer-Verlag Berlin Heidelberg 2016

\begin{abstract}
Nitrate contamination in both surface water and groundwater has received considerable attentions in irrigated agricultural areas. Nitrate concentrations, and its nitrogen and oxygen isotopic compositions, as well as oxygen and deuterium isotopic compositions and chloride concentrations of surface water and groundwater from a typical area in the lower reaches of the Yellow River irrigation district were analyzed to ascertain spatial variations of nitrate and its possible sources and transformations. The results of this study showed nitrate in the Yellow River mainly derived from mineralization of organic matter in sediments and nitrification of atmospheric deposition, and nitrate in other important tributaries were greatly affected by agricultural activities, especially synthetic fertilizer. Nitrate in irrigation canals which go through concentrated residential zone mainly originated from domestic effluent and experienced nitrification. Nitrate in groundwater is not only affected by surface nitrate sources, but also closely related to hydraulic conditions which make nitrate source discrimination more complex. In areas belonging to the Yellow River basin with shallow water tables, nitrate is mainly derived from synthetic fertilizer, and denitrification processes controlled nitrate isotopic compositions in extremely shallow groundwater with low hydraulic gradients. While in places belonging to
\end{abstract}

Xianfang Song

songxf@igsnrr.ac.cn

1 Key Laboratory of Water Cycle and Related Land Surface Processes, Institute of Geographic Sciences and Natural Resources Research, Chinese Academy of Sciences, Beijing 100101, China

2 Graduate University of Chinese Academy of Sciences, Beijing 100049, China

3 Sino-Danish Center for Education and Research, Beijing 100190, China the Haihe River basin with deep water table, groundwater nitrate is largely affected by mixing process of irrigation water. The main sources of nitrate in groundwater are manure and sewage and soil organic matter, while chemical fertilizer and atmospheric deposition in large amount of rainfall are its minor contributors.

Keywords Nitrate isotope - Source identification · Irrigation region $\cdot$ Surface water $\cdot$ Groundwater

\section{Introduction}

As the main existing form of nitrogen, nitrate $\left(\mathrm{NO}_{3}^{-}\right)$is found naturally in the environment (Appelo and Postma 2005). Since the 1970s, nitrate in water has received considerable attention due to its environmental and health effects. Previous studies show that high concentration of nitrate can be related to some specific forms of cancer and methemoglobinemia (Fan and Steinberg 1996; Fewtrell 2004), eutrophication and seasonal hypoxia in estuaries and coastal oceans (McIsaac et al. 2001). Nitrate contamination in water bodies was reported from all parts of the world. A survey of farm drinking water quality conducted through the province of Ontario, Canada, in 1991 and 1992 showed about $14 \%$ of 1292 wells with $\mathrm{NO}_{3}-\mathrm{N}$ concentrations above $10 \mathrm{mg} / \mathrm{L}$ limit (Goss et al. 1998). The nitrate concentration of alluvial groundwaters in the Nakdong River basin, Korea, varied widely from below the detection limit to $383.4 \mathrm{mg} / \mathrm{L}\left(\mathrm{NO}_{3}^{-}\right)$with the median nitrate concentration of $55.4 \mathrm{mg} / \mathrm{L}$ (Min et al. 2002), and in China nitrate was detected (detection threshold of $0.2 \mathrm{~N} \mathrm{mg} / \mathrm{L}$ ) in $96 \%$ of all groundwater and $28 \%$ of groundwater samples exceeded WHO's drinking water standard of $50 \mathrm{NO}_{3}^{-} \mathrm{mg} / \mathrm{L}$ (Gu et al. 2013; WHO 2011). Nitrate in water has many 
potential sources, including non-point sources such as atmospheric deposition, soil organic matter and nitrogen fertilizer and pesticides application in agricultural activities, and point sources including discharge of urban domestic sewage, industrial wastewater, septic tanks and landfills.

Accurate source identification is critical for reasonable protection and prevention of water from nitrate contamination. Nitrogen isotopes $\left(\delta^{15} \mathrm{~N}\right)$ in nitrate have been widely used for nitrate source discrimination over the past several decades because different sources of nitrate often have distinct isotopic compositions (Heaton 1986; Kendall et al. 2008; Kohl et al. 1971). Using atmospheric $\mathrm{N}_{2}$ isotopic composition as standard $(0 \%)$, synthetic fertilizer produced by fixation of atmospheric $\mathrm{N}_{2}$ often has lower $\delta^{15} \mathrm{~N}$ values, generally in the range of -4 to $+4 \%$ (Kendall et al. 2008), soil $\mathrm{N}$ has slightly higher $\delta^{15} \mathrm{~N}$ values from 0 to $+8 \%$ linked to the relative rate of mineralization and nitrification, and manure and sewage are enriched in ${ }^{15} \mathrm{~N}$ due to large fractionation during volatilization of ${ }^{15} \mathrm{~N}$-depleted ammonia and conversion of $\mathrm{NH}_{4}^{+}$into ${ }^{15} \mathrm{~N}$ enriched $\mathrm{NO}_{3}^{-}$with $\delta^{15} \mathrm{~N}$ values of $\mathrm{NO}_{3}^{-}$originating from manure is between +5 and $+25 \%$ and sewage between +4 and $+19 \%$ (Xue et al. 2009). And $\delta^{15} \mathrm{~N}$ values of atmospheric $\mathrm{N}$ deposition have a wide range from -13 to $+13 \%$ due to multiple effects of chemical reaction in the atmosphere and various anthropogenic sources such as combustion of fossil fuels (Xue et al. 2009). Nitrate derived from synthetic fertilizer ( -4 to $+4 \%$ ) versus animal waste $(+5$ to $+25 \%$ o can be differentiated successfully using $\delta^{15} \mathrm{~N}$ alone due to their distinct isotopic composition ranges, while nitrate derived from atmospheric deposition and chemical fertilizer cannot be discriminated depending on $\delta^{15} \mathrm{~N}$ values only, because of their overlapping ranges. Since the early 1990 s, oxygen isotopes $\left(\delta^{18} \mathrm{O}\right)$ in nitrate have been used as an additional tool for nitrate source discrimination and process analysis, owing to larger differences in its isotopic signatures than $\delta^{15} \mathrm{~N}$ between atmospheric $\mathrm{NO}_{3}^{-}$(from +52.5 to $+60.9 \%$ ) and microbially produced soil $\mathrm{NO}_{3}^{-}$(from +0.8 to $+5.8 \%$ ) (Durka et al. 1994; Kendall et al. 1995; Kendall and McDonnell 2012; Xue et al. 2009). Nitrate-nitrogen and nitrate-oxygen dual isotope methods have been successfully used for nitrate sources identification in both urban and agriculture rivers, small and large river basins, wetland and coastal system, surface and groundwater systems (Battaglin et al. 2001; Campbell et al. 2002; Kendall et al. 2008; Wankel et al. 2006).

An understanding of how biogeochemical cycling affects the isotopic composition is a prerequisite for correct and reasonable application of isotopes as tracers of various sources. It has been recognized for several decades that nitrate-consuming processes including assimilation and denitrification can cause "coupled" enrichment of $\delta^{15} \mathrm{~N}$ and $\delta^{18} \mathrm{O}$ in the remaining pool of $\mathrm{NO}_{3}^{-}$(Granger et al. 2004). A large amount of datasets suggested relatively consistent patterns that nitrate $\delta^{15} \mathrm{~N}$ and $\delta^{18} \mathrm{O}$ values in areas where denitrification occurred are likely plotting along slopes of 0.5-0.7 (Kendall et al. 2008). Compared to "coupled" isotopic effects during denitrification and assimilation, nitrification can be considered as "decoupled" process because sources of nitrogen and oxygen atoms are unrelated (Kendall and McDonnell 2012). However, after several researchers' work (Andersson and Hooper 1983; DiSpirito and Hooper 1986; Hollocher et al. 1981), the current understanding is that two oxygen atoms in $\mathrm{NO}_{3}^{-}$derive from $\mathrm{H}_{2} \mathrm{O}$ and another one derives from $\mathrm{O}_{2}$, and there may be further $\mathrm{O}$ exchange between nitrate and water. Therefore, $\delta^{18} \mathrm{O}$ in ambient water has been linked with $\delta^{18} \mathrm{O}$ in nitrate to explore nitrification process (Andersson and Hooper 1983). Lee et al. (2008) observed a good positive correlation between $\delta^{18} \mathrm{O}_{\mathrm{H}_{2} \mathrm{O}}$ and $\delta^{18} \mathrm{O}_{\mathrm{NO}_{3}^{-}}$in Han River, which suggested $\delta^{18} \mathrm{O}_{\mathrm{NO}_{3}^{-}}$values are controlled by $\delta^{18} \mathrm{O}_{\mathrm{H}_{2} \mathrm{O}}$ during microbial nitrification.

The Yellow River irrigation region at the lower reaches is located in Henan and Shandong provinces which plays an important role in food production in China, with total irrigation area of $186 \times 10^{4} \mathrm{hm}^{2}$ and annual average water diversions of around $1 \times 10^{10} \mathrm{~m}^{3}$ (Ren and Tang 1998). Compared to widespread water scarcity in most regions of North China plain (NCP), the Yellow River irrigation area in the lower reaches usually has shallower water table because of lateral seepage from the Yellow River and vertical recharge from surface irrigation (Shen et al. 2011). In the process of water movement, large amount of nitrate residue in the soil resulted from excessive application of synthetic fertilizer, will move along with water flow due to its good solubility in water and not readily absorbed by soil colloids. Apart from the effect of agricultural activities on nitrate in groundwater, other sources including municipal sewage, industrial wastewater and other point sources (landfills, septic tanks) have been discussed in recent years. In addition, because of the large amount of diverted water used for irrigation, the Yellow River water and its tributaries, which usually have higher nitrate concentrations than precipitation, also contribute to the nitrate in groundwater (Chen et al. 2007). Previous studies conducted in North China plain suggested that groundwater nitrate is also related to the geological setting, and groundwater flow system controls accumulation patterns of nitrate (Chen et al. 2005). Study result of environmental isotopes in a typical irrigation region located in NCP showed that the 
main sources of nitrate in surface water were nitrification of fertilizer and sewage and mineralization of soil organic $\mathrm{N}$ and sewage mainly contributed to nitrate in groundwater during dry season (Zhang et al. 2014).

Puyang Yellow River (PYR) irrigation region is chose as the case study region due to its special geographical location and over 30 years of irrigation history. In this study, we have analyzed the dissolved anions and isotopic compositions of dissolved nitrate in both surface and groundwater. Comparative analysis of hydrochemical and isotopic characteristics between surface and groundwater sheds light on the interaction between different water bodies and different nitrate sources for different water bodies.

\section{Materials and methods}

\section{Study region description}

Puyang Yellow River (PYR) irrigation region is located in the junction of Shandong, Hebei and Henan provinces, in the northern area of Henan Province (China) (Fig. 1). It covers an area of about $3150 \mathrm{~km}^{2}$ and has a population of over 2.890 million. The study area has a continental monsoon climate with four distinct seasons, sandy-dry spring, hot-wet summer, clear-sunny autumn and cold-dry winter (Lu et al. 2014). The monthly average temperatures vary from $-1.6{ }^{\circ} \mathrm{C}$ in January to $26.8{ }^{\circ} \mathrm{C}$ in July (Liu et al. 2010). The average annual precipitation (1960-2008) is $644.4 \mathrm{~mm}$, with over $65 \%$ of the annual precipitation falling during June and September (Liu et al. 2010).

Based on the 2000 national land-use data $(1 \mathrm{~km} \times 1 \mathrm{~km}) \quad$ (http://www.geodata.cn/Portal/metadata/ viewMetadata.jsp?id=100101-43\&isCookieChecked=true), the dominant land-use type is arable land accounting for $82.54 \%$ of the total area, of which $98.57 \%$ is dry land and $1.43 \%$ is paddy field. Land used for industries and residents accounts for another $15.79 \%$, other land-use types including grass, forest and water areas together are less than $2 \%$. According to annual Puyang statistical yearbook, fertilizer application in Puyang has increased from 161,179 tons in 1999 to 276,262 tons in 2013, with nitrogen fertilizer increased from 87,212 tons in 1999 to 125,108 tons in 2013.

There are nearly 90 tributaries which are mostly medium and small rivers, belong to the Yellow River basin (YRB) and Haihe River basin (HHB) with the Jindi River as their boundary. Among them, the Yellow River (YR), Jindi River (JDH), Majia River (MJH) and Zhulong River (ZLH) are the most important rivers (Fig. 1). Except natural tributaries, irrigation canals also constitute another important part of surface water system in PYR. The First PQN irrigation canal (FPQN), the Second irrigation canal (SPQN) and the Third irrigation canal (TPQN) are the most important canals transporting water from south to north, with the Yellow River as their common source that located in the southernmost of study area. The SPQN and TPQN go through the whole study area from south to north and cross JDH through inversed siphon beneath, and the FPQN enters into $\mathrm{MJH}$ in its lower reaches after $35 \mathrm{~km}$ away from the Yellow River (Fig. 1). The study is divided by the Jindi River, with the northern region belonging to the Haihe River Basin, and the southern area is part of the Yellow River basin.

As a part of the Yellow River alluvial plain, PYR irrigation region is mainly built up by river deposits with the loose bed thickness of the Quaternary system ranging from 350 to $400 \mathrm{~m}$. Based on its stratum structure, it is usually divided into two different aquifer groups, a shallow unconfined aquifer less than $150 \mathrm{~m}$ and a deep confined aquifer between 150 and $300 \mathrm{~m}$. The shallow aquifer and deeper aquifer are separated by claypan with weak permeability (Li and Song 2004). In study area, groundwater hydraulic connection between YRB and $\mathrm{HHB}$ is poor because of clay stratum associated with the JDH which has low hydraulic conductivity. In addition, field measurement suggested that affected by lateral seepage of the Yellow River, water table in YRB often ranges from 2 to $8 \mathrm{~m}$, while in HHB water table falls below $15 \mathrm{~m}$ and even deeper (Fig. 1). Groundwater heads are generally higher in the southern part and lower in the northern region. Generally speaking, groundwater in study area flows from south to north with part area located in river confluence reaches in HHB has dispersed flow to all directions.

\section{Water sampling}

According to instruction of water samples collection and preservation in the drinking water standard examination method (GB/T5750-2006), all of the surface water and groundwater samples were collected and preserved within one week in August 2013 (1 August through 6 August). Additionally, five surface water samples were collected from different rivers located in the study area, and the other 12 samples were collected at different sites from the irrigation canals. Eighteen shallow groundwater samples in HHB and another seven samples in YRB were collected respectively (Fig. 1). Wells were purged by pumping at least three well volumes of water prior to sampling. All samples were stored at $4{ }^{\circ} \mathrm{C}$ after bottling.

\section{Analytical techniques}

Electrical conductivity (EC), water temperature (T), $\mathrm{pH}$ and dissolved oxygen (DO) were measured in situ using 


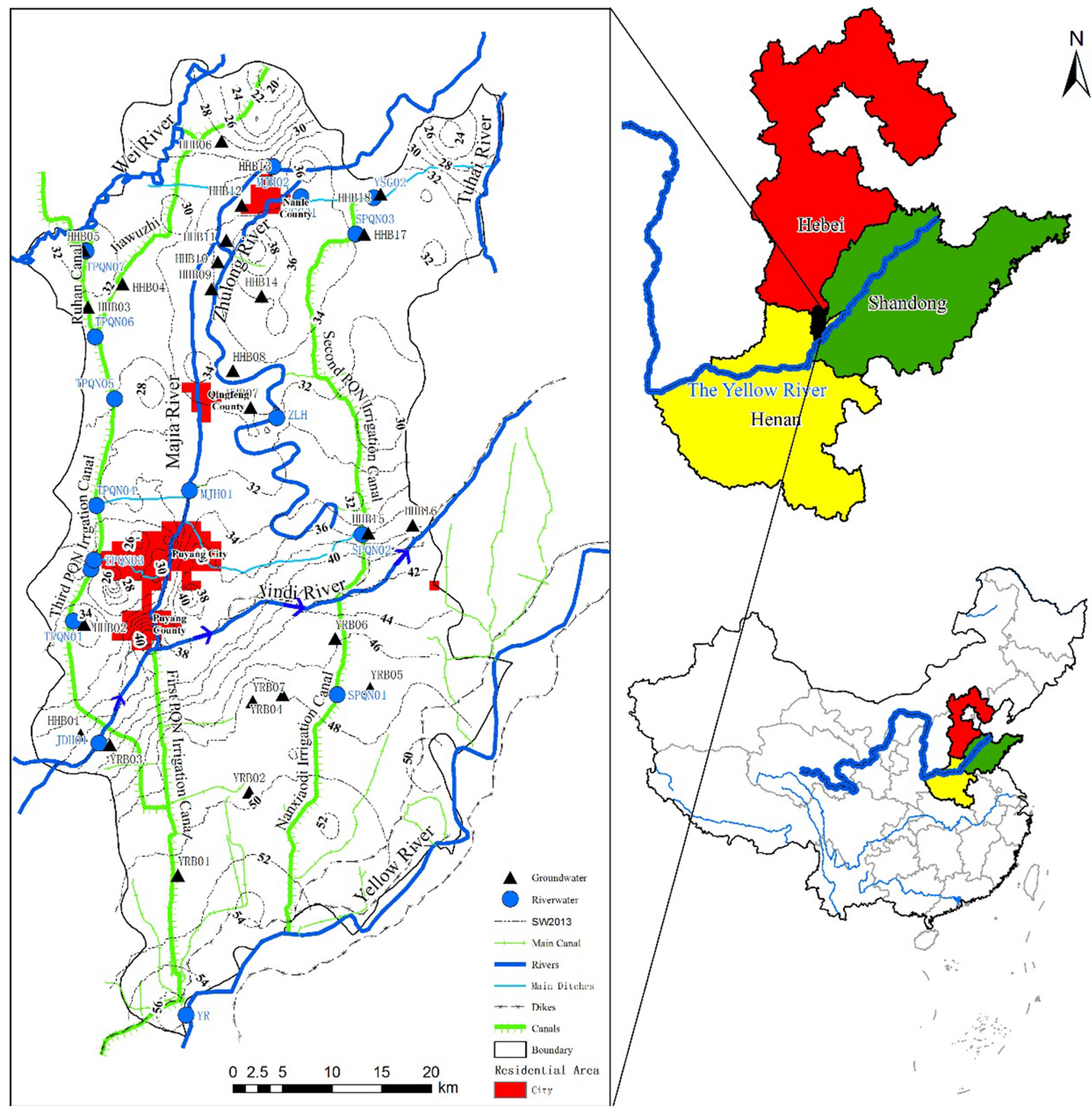

Fig. 1 Location of the Puyang Yellow River irrigation district in its lower reaches, the Yellow River basin (YRB) and Haihe River basin (HHB) are in the southern and northern part, respectively, with Jindi River as their boundary

multi-parameter portable meter (HACH40d, USA), which was previously calibrated. Alkalinity was determined by titration with $0.01 \mathrm{M} \mathrm{H}_{2} \mathrm{SO}_{4}$ against methyl orange within $12 \mathrm{~h}$. All water samples for chemical analysis and isotopic composition were filtrated going through $0.45-\mu \mathrm{g}$ filter (Millipore cellulose acetate membrane) before laboratory analysis. Anions including $\mathrm{Cl}^{-}$and $\left(\mathrm{NO}_{3}^{-}\right)$were analyzed using ICS-2100 Integrated IC System (Thermo Scientific $\left.{ }^{\mathrm{TM}}\right)$.
Hydrogen and oxygen stable isotopes in $\mathrm{H}_{2} \mathrm{O}$ were measured using liquid water isotope analyzer (DLT-100, Los Gatos Research Inc., USA). Nitrate stable isotope sample collection and analysis were done following the procedures of Silva et al. (2000). Nitrate was extracted using the anion exchange resin method, and its isotopes were determined using Finnigan MAT253 mass spectrometer combined with an online Flash Elemental Analyzer. All stable isotope analysis data were reported in per 
mill (\%) relative to international standard (V-SMOW for hydrogen and oxygen isotopes and air for nitrogen isotope). All of the water samples were treated and analyzed in the physical and chemical analysis center laboratory of the Institute of Geographic Sciences and Natural Resources Research (IGSNRR), Chinese Academy of Sciences (CAS).

\section{Results}

\section{Water chemistry and isotopic compositions}

The $\mathrm{NO}_{3}^{-}$concentrations in both surface water and groundwater have wide ranges with the highest value of 108.76 and $439.06 \mathrm{mg} / \mathrm{L}$. A wider range of $\mathrm{NO}_{3}^{-}$concentrations was observed in rivers than that in irrigation canals with mean values of 40.37 and $18.86 \mathrm{mg} / \mathrm{L}$, respectively. Compared with $\mathrm{pH}$ values in surface water (7.34-8.13), groundwater samples have a slightly higher $\mathrm{pH}$ values ranging from 7.64 to 8.45 . The observed dissolved oxygen (DO) concentrations in surface water were generally higher than those in groundwater, with average value of 7.79 and $3.32 \mathrm{mg} / \mathrm{L}$, respectively. Natural river has the lowest electrical conductivity (EC) value $(1102.9 \mu \mathrm{S} / \mathrm{cm})$, and groundwater samples have higher $\mathrm{EC}$ values with average value of $1844.7 \mu \mathrm{S} / \mathrm{cm}$ in YRB and $2070.3 \mu \mathrm{S} / \mathrm{cm}$ in HHB; samples from irrigation canals have the highest ECs with mean value of $2860.2 \mu \mathrm{S} / \mathrm{cm}$. The $\mathrm{Cl}^{-}$concentrations in surface water have wide ranges in surface water, with the ranges between 22.4 and $1198.8 \mathrm{mg} / \mathrm{L}$ in irrigation canals and 57.9-211.4 mg/L in rivers. And the $\mathrm{Cl}^{-}$concentrations in groundwater didn't show significant differences with mean value of 211.3 and $213.6 \mathrm{mg} / \mathrm{L}$ in $\mathrm{YRB}$ and HHB.

The $\delta \mathrm{D}$ values in surface water vary from -69.04 to $-52.84 \%$ and $\delta^{18} \mathrm{O}$ values vary from -9.62 to $-7.15 \%$. Compared to surface water, groundwater has narrower range from -67.12 to $-56.12 \%$ for $\delta \mathrm{D}$ and from -9.08 to $-7.30 \%$ for $\delta^{18} \mathrm{O}$. The $\delta \mathrm{D}$ and $\delta^{18} \mathrm{O}$ values of the Yellow River were -67.88 and $-9.46 \%$, respectively.

\section{Nitrogen and oxygen isotopes in nitrate}

In general, the lighter isotope reacts more readily, resulting in the increase in the $\delta^{15} \mathrm{~N}$ of the substrate, and decreases in the products. Stable isotope composition of nitrogen in nitrate has been used extensively to provide information on the origins and transformations of nitrate in different water bodies due to the characteristics of different isotopic compositions in different formation process and transformation processes (Heaton 1986; Kendall and Aravena
2000; Kohl et al. 1971; Liu et al. 2006). The $\delta^{15} \mathrm{~N}$ of $\mathrm{NO}_{3}^{-}$ varies from +2.69 to $+26.17 \% \quad(n=10$, mean $+12.40 \%$ ) in irrigation canals and varies from +2.25 to $+20.00 \%$ o $(n=7$, mean $+11.03 \%)$ in rivers. The mean values of $\delta^{15} \mathrm{~N}_{\mathrm{NO}_{3}^{-}}$in YRB and $\mathrm{HHB}$ were $+13.14 \%$ $(n=7,+0.30$ to $+26.19 \%)$ and $+10.05 \%$ ( $n=18$, +4.13 to $+15.70 \%$ ), respectively.

Due to different sources for oxygen atoms in $\mathrm{NO}_{3}^{-}$in different cycling processes, there are distinct $\delta^{18} \mathrm{O}_{\mathrm{NO}_{3}^{-}}$ values between atmospheric $\mathrm{NO}_{3}^{-}$(from +52.5 to $+60.9 \%$ ) and microbially produced soil $\mathrm{NO}_{3}^{-}$(from +0.8 to $+5.8 \%$ ) (Xue et al. 2009), and natural fertilizer (from +46 to $+58 \%$ ) and synthetic nitrate fertilizer (from +17 to $+25 \%$ ) and ammonium fertilizer (from -5 to $+15 \%$ ) (Kendall et al. 2008). The $\delta^{18} \mathrm{O}$ of $\mathrm{NO}_{3}^{-}$ provided a further indication of sources and transformation of nitrate in surface and groundwater (Liu et al. 2006). The $\delta^{18} \mathrm{O}_{\mathrm{NO}_{3}^{-}}$value ranged from -4.01 to $+15.13 \%$ with an average value of $+4.21 \%$ in canals and within the range from -4.87 to $+16.61 \%$ in rivers. The $\delta^{18} \mathrm{O}_{\mathrm{NO}_{3}^{-}}$average values of groundwater in YRB and HHB were +1.31 and $+3.32 \%$, which were slightly lower than that in surface water. Overall an overwhelming majority of samples fell into the range indicative of microbiological process with one sample with $\delta^{18} \mathrm{O}_{\mathrm{NO}_{3}^{-}}$value of $+16.61 \%$ slightly beyond the scope of microbiological effect.

Based on the previous review of typical $\delta^{15} \mathrm{~N}_{\mathrm{NO}_{3}^{-}}$and $\delta^{18} \mathrm{O}_{\mathrm{NO}_{3}^{-}}$range indicative of different nitrate sources (Kendall et al. 2008; Kendall and McDonnell 2012; Xue et al. 2009), $\delta^{15} \mathrm{~N}_{\mathrm{NO}_{3}^{-}}$and $\delta^{18} \mathrm{O}_{\mathrm{NO}_{3}^{-}}$values of surface and groundwater are listed in Fig. 2. In general, the $\delta^{15} \mathrm{~N}_{\mathrm{NO}_{3}^{-}}$

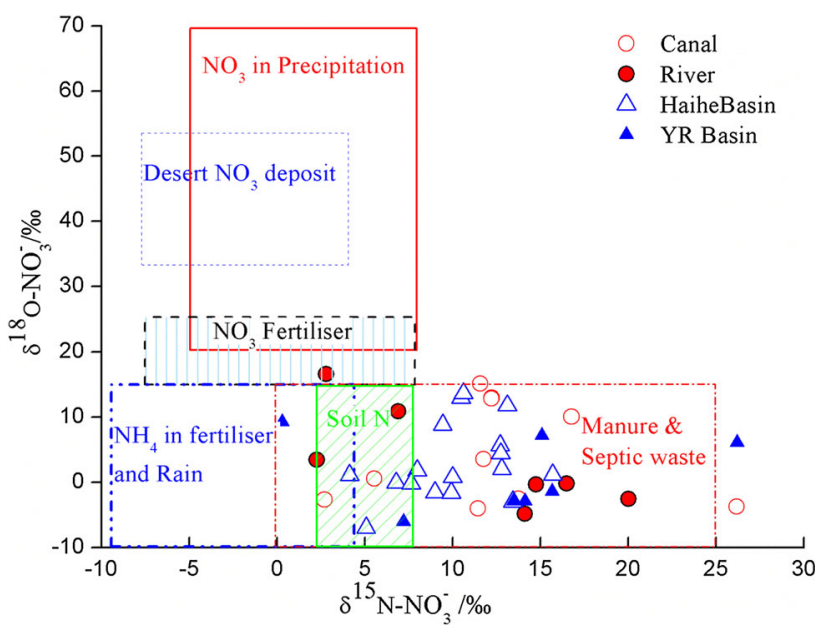

Fig. 2 Dual isotopic compositions of nitrate in the lower reaches of the Yellow River irrigation district $\left(\delta^{18} \mathrm{O}-\mathrm{NO}_{3}^{-}\right.$vs. $\left.\delta^{15} \mathrm{~N}-\mathrm{NO}_{3}^{-}\right)$and typical ranges indicative of different nitrate sources 
values in the surface water varied from +2.25 to $+26.17 \%$ with an average of $11.84 \pm 6.41 \%$, and their $\delta^{18} \mathrm{O}_{\mathrm{NO}_{3}^{-}}$values varied from -4.87 to $+16.61 \%$ with mean value of $3.83 \pm 7.53 \%(n=17)$. The $\delta^{15} \mathrm{~N}_{\mathrm{NO}_{3}^{-}}$ values in groundwater were in the similar range to those of surface water, with slightly low mean value $(10.91 \pm 4.95)$ and smaller variation. The $\delta^{18} \mathrm{O}_{\mathrm{NO}_{3}^{-}}$values in groundwater fell into the range between -6.98 and $+13.64 \%$ with the mean value of $2.76 \pm 5.82 \%(n=25)$. The smaller variation of $\delta^{15} \mathrm{~N}_{\mathrm{NO}_{3}^{-}}$and $\delta^{18} \mathrm{O}_{\mathrm{NO}_{3}^{-}}$values in groundwater than that in surface water illustrated more direct effects of different nitrate sources on surface water than groundwater which receives water infiltrated by soil. The lower $\delta^{18} \mathrm{O}_{\mathrm{NO}_{3}^{-}}$ value in groundwater may result from more microbial processes during vadose zone.

\section{Discussion}

\section{Mixing processes}

Even though low concentration of $\mathrm{NO}_{3}^{-}$usually indicates natural sources while high levels of concentration means anthropogenic inputs, it is often difficult to judge nitrate source only based on nitrate concentration due to a variety of different nitrogen chemical forms and transformation processes which probably exerting effects on nitrate concentration. Therefore, $\mathrm{Cl}^{-}$is often used in combination with $\mathrm{NO}_{3}^{-}$to distinguish mixing process from transformation process, because $\mathrm{Cl}^{-}$is usually considered as a conservative tracer which is not subject to physical, chemical and microbiological processes (Altman and Parizek 1995; Liu et al. 2006; Mengis et al. 1999). In general, there is no clear correlation between $\mathrm{NO}_{3}^{-}$and $\mathrm{Cl}^{-}$which indicates that no simple mixing process is responsible for the change of $\mathrm{NO}_{3}^{-}$concentration in surface water or groundwater (Fig. 3). But it is worth noting the close relationship between $\mathrm{NO}_{3}^{-}$and $\mathrm{Cl}^{-}$in $\mathrm{HHB}$ where $\mathrm{Cl}^{-}$concentrations are less than $200 \mathrm{mg} / \mathrm{L}$, which suggests that mixing processes partly contribute to enrichment of nitrate in groundwater in HHB.

Potential sources for $\mathrm{Cl}^{-}$include natural sources (atmospheric deposition, dissolution of halite), agricultural chemicals and other anthropogenic sources, such as sewage effluent and industrial wastewater. Previous studies show there are no rock salts or evaporite sediments and $\mathrm{Cl}^{-}$from chemical fertilizer usually come along with increase of $\mathrm{NO}_{3}^{-}$concentration. Therefore, extremely high $\mathrm{Cl}^{-}$concentration with relative low $\mathrm{NO}_{3}^{-}$often indicates contaminant of domestic sewage and industrial wastewater. Water

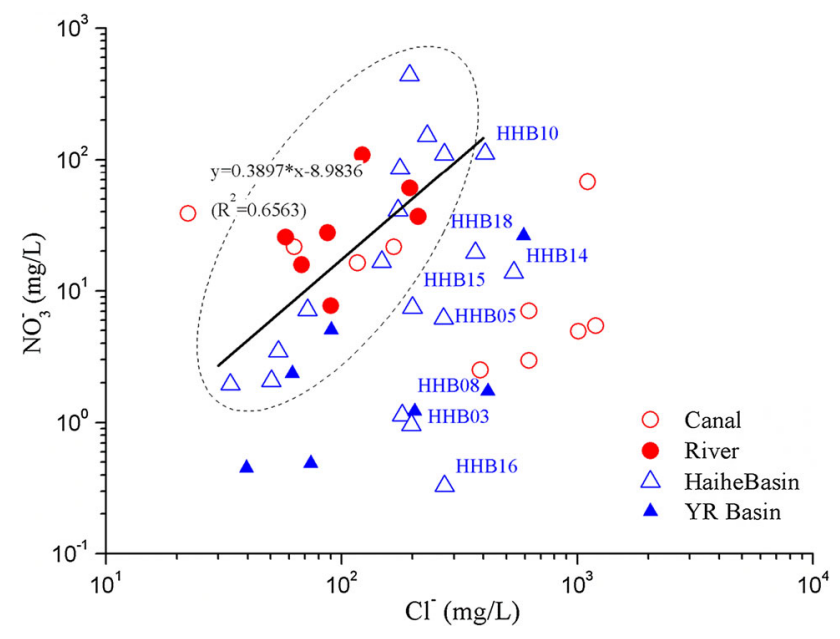

Fig. 3 Scatter plot of $\mathrm{NO}_{3}^{-}$versus $\mathrm{Cl}^{-}$in the irrigation district

samples from irrigation canals with $\mathrm{Cl}^{-}$concentration of over $1000 \mathrm{mg} / \mathrm{L}$ probably have been contaminated by municipal sewage or local industrial wastewater.

The plot of $\mathrm{NO}_{3}^{-} / \mathrm{Cl}^{-}$molar ratio versus $\mathrm{Cl}^{-}$concentration can be used to discriminate agricultural inputs from municipal inputs (Liu et al. 2006). In agricultural areas, $\mathrm{NO}_{3}^{-}$in water bodies is inevitably linked to fertilizer application rate (Böhlke and Denver 1995). Because urea the commonly used nitrogen fertilizer in North China plain and mineralization of soil organic $\mathrm{N}$ do not contain $\mathrm{Cl}^{-}$ (Mengis et al. 1999), high $\mathrm{NO}_{3}^{-} / \mathrm{Cl}^{-}$often suggests nitrate mainly derived from agricultural fertilizer application. While municipal sewage and animal manure are rich in $\mathrm{Cl}^{-}$with low $\mathrm{NO}_{3}^{-}$, low $\mathrm{NO}_{3}^{-} / \mathrm{Cl}^{-}$along with high $\mathrm{Cl}^{-}$ concentration can be used to indicate municipal inputs. When there is no significant change in $\mathrm{Cl}^{-}$concentration, which suggests no obvious mixing process occurring, decrease in $\mathrm{NO}_{3}^{-} / \mathrm{Cl}^{-}$ratios probably results from $\mathrm{NO}_{3}^{-}$ consuming processes such as denitrification. It can be easily observed that $\mathrm{NO}_{3}^{-}$in part of irrigation canals was mainly resulted from municipal effluent, and $\mathrm{NO}_{3}^{-}$in rivers and groundwater in HHB may be the combined result of multisource (Fig. 4). The $\mathrm{NO}_{3}^{-} / \mathrm{Cl}^{-}$ratios in YRB decreased with $\mathrm{Cl}^{-}$remaining the same, which could be attributed to nitrate-consuming processes such as denitrification.

\section{Possible isotopic fractionation processes}

The basic premium for nitrate-nitrogen and nitrate-oxygen stable isotopes discriminating different nitrate sources to aquatic system reasonably is to ensure isotopic compositions representative of original sources without any considerable fractionation, which relies on an understanding of how different biogeochemical cycling affects the isotopic 


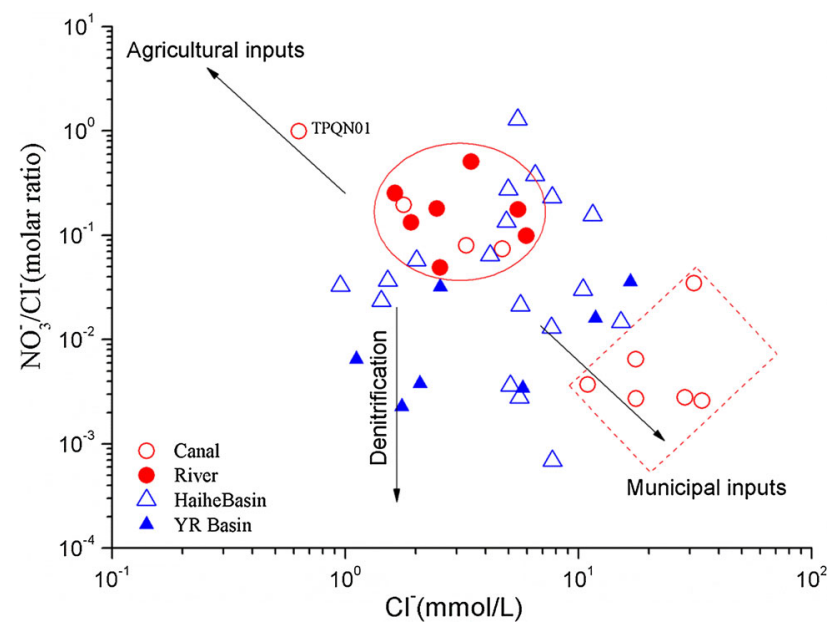

Fig. 4 Plot of $\mathrm{NO}_{3}^{-} / \mathrm{Cl}^{-}$molar ratio versus $\mathrm{Cl}^{-}$concentration in the lower reaches of the Yellow River irrigation region

composition of $\mathrm{NO}_{3}^{-}$(Kendall et al. 2008). In the whole $\mathrm{N}$ cycling processes, isotopic fractionations of $\delta^{15} \mathrm{~N}$ almost happened in every major processes including atmospheric $\mathrm{N}_{2}$ fixation, organic matter mineralization, ammonium nitrification, nitrate denitrification, assimilation and ammonia volatilization (Robinson 2001). Of which, denitrification of $\mathrm{NO}_{3}^{-}$, assimilation of $\mathrm{NO}_{3}^{-}$by plants/microbes and nitrification of $\mathrm{NH}_{2}^{-} / \mathrm{NH}_{4}^{+}$are directly related to measured value of $\delta^{15} \mathrm{~N}$ in nitrate.

Denitrification is a multi-step reduction process of $\mathrm{NO}_{3}^{-}$ to gaseous products $\left(\mathrm{N}_{2}, \mathrm{~N}_{2} \mathrm{O}\right.$ or $\left.\mathrm{NO}\right)$ which usually only occurs where $\mathrm{O}_{2}$ concentration are less than $20 \mu \mathrm{M}$ (Kendall and Aravena 2000; Kendall et al. 2008; Kendall and McDonnell 2012). It has been found that in a closed system, denitrification is not only accompanied by disappearance of dissolved $\mathrm{O}_{2}$, appearance of $\mathrm{Mn}^{2+}$ and $\mathrm{Fe}^{2+}$ (Mariotti et al. 1988) and increases of water alkalinity because of organic matter oxidation, but also causes exponentially increase in $\delta^{15} \mathrm{~N}$ and $\delta^{18} \mathrm{O}$ in the remaining $\mathrm{NO}_{3}^{-}$in specific ratios as $\mathrm{NO}_{3}^{-}$decreased (Böttcher et al. 1990). Along with the decrease of $\mathrm{NO}_{3}^{-}$concentration, there are no clear increase trends in neither $\delta^{18} \mathrm{O}_{\mathrm{NO}_{3}^{-}}$nor $\delta^{18} \mathrm{O}_{\mathrm{NO}_{3}^{-}}$values (Fig. 5), which indicated denitrification process cannot be mainly responsible for the shifts in isotopic compositions of nitrate. Plot of $\delta^{18} \mathrm{O}_{\mathrm{NO}_{3}^{-}}$versus $\delta^{15} \mathrm{~N}_{\mathrm{NO}_{3}^{-}}$in Fig. 6b showed that groundwater samples took from YRB had the $\delta^{18} \mathrm{O} / \delta^{15} \mathrm{~N}$ ratio between 0.5 and 0.7 . YRB02, YRB04, YRB05, YRB06 and YRB07 were located in the eastern part of YRB with shallow water table and extremely low hydraulic gradients which makes denitrification possible. Groundwater with low hydraulic gradients usually remains long time in the same place, and with the
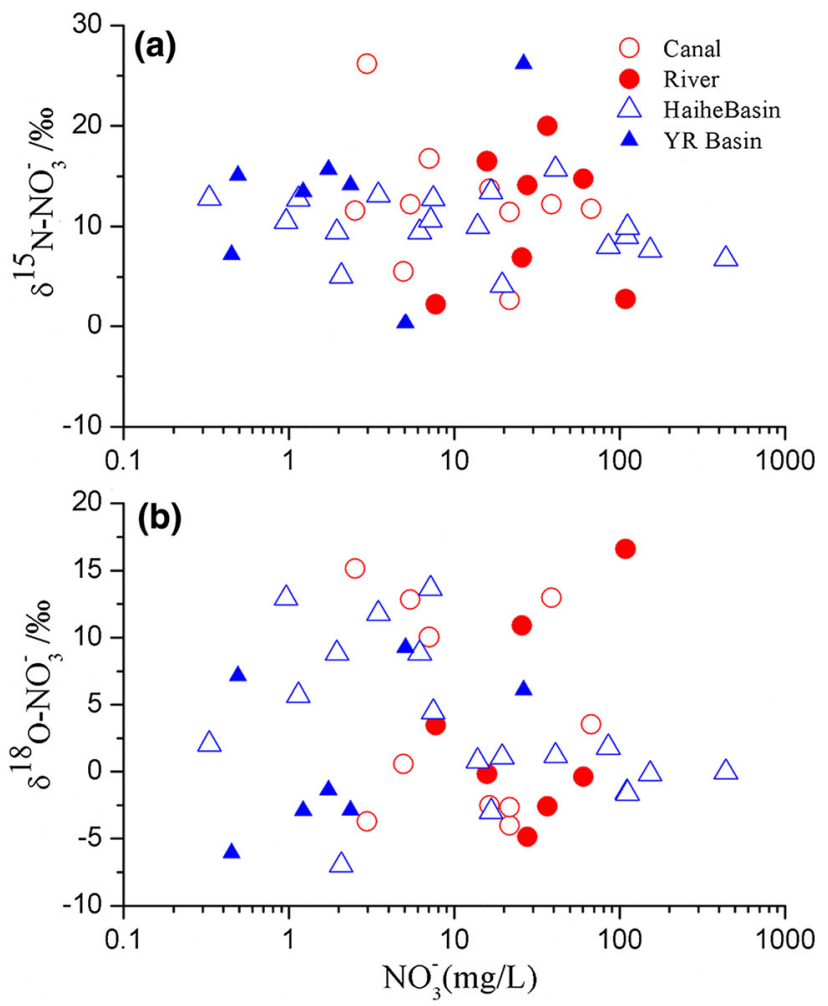

Fig. $5 \mathrm{NO}_{3}$ isotopic compositions versus $\mathrm{NO}_{3}^{-}$concentration in the lower reaches of the Yellow River irrigation district a $\delta^{15} \mathrm{~N}-\mathrm{NO}_{3}^{-}$ versus $\mathrm{NO}_{3}^{-}$concentration. $\mathbf{b} \delta^{18} \mathrm{O}-\mathrm{NO}_{3}^{-}$versus $\mathrm{NO}_{3}^{-}$concentration

proceeding of oxygen consuming process, available oxygen in the groundwater is quite limited which benefits to denitrification.

Nitrification is a multi-step oxidation process resulting in nitrate as main product and also other nitrogen oxides as its intermediate species. In general, the extent of fractionation during nitrification is dependent on the substrate pool that can be consumed; nitrification is diffusion limited at low ammonium concentration, and only stimulated when there is a large amount of ammonium available which will result in a large fractionation and $\delta^{15} \mathrm{~N}$ value of the first formed $\mathrm{NO}_{3}^{-}$would be quite low (Kendall and McDonnell 2012). The $\delta^{15} \mathrm{~N}$ value at TPQN02 site is $11.75 \%$ and decreased sharply to $5.52 \%$ at TPQN03 which is located in the downstream with the distance less than $1 \mathrm{~km}$. At the same time, DO concentration also decreased accordingly from $3.17 \mathrm{mg} / \mathrm{L}$ at TPQN02 to $0.78 \mathrm{mg} / \mathrm{L}$ at TPQN03, which is resulted from nitrification of ammonium consumed large amount of dissolved oxygen. In addition, because there is a release of hydrogen ions during nitrification (Anthonisen et al. 1976), decrease of $\mathrm{pH}$ to an extent can be another evidence of nitrification with $\mathrm{pH}$ value from 8.13 at TPQN02 to 7.58 at TPQN03. However, with the 

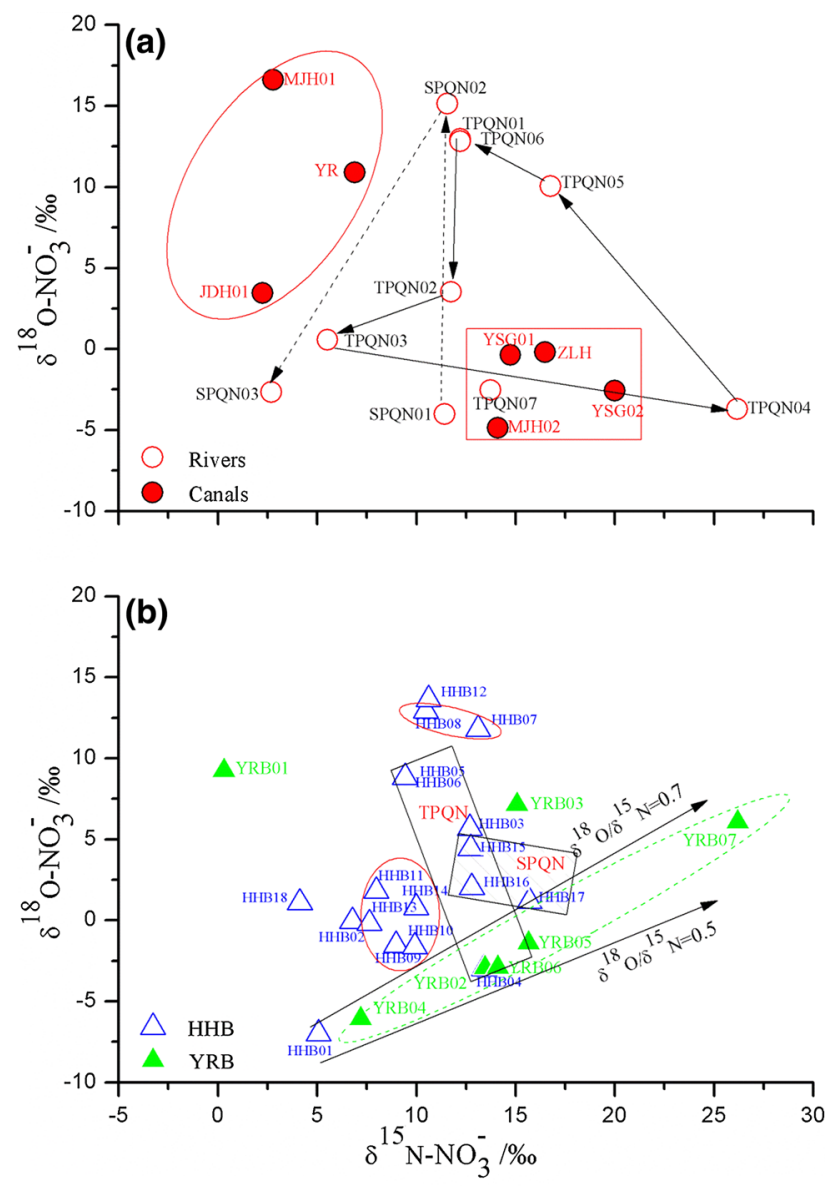

Fig. $6 \delta^{18} \mathrm{O}-\mathrm{NO}_{3}^{-}$versus $\delta^{15} \mathrm{~N}-\mathrm{NO}_{3}^{-}$for a surface water samples and $\mathbf{b}$ groundwater samples

consumption of $\mathrm{NH}_{4}^{+}$pool, nitrification rate usually decreased with the $\delta^{15} \mathrm{~N}$ of the total $\mathrm{NO}_{3}^{-}$increased to prefertilization values (Feigin et al. 1974). The $\delta^{15} \mathrm{~N}$ value of nitrate increased from $5.52 \%$ at TPQN03 to $16.76 \%$ at TPQN05. Because the source of $\mathrm{N}$ and $\mathrm{O}$ atoms during nitrification is unrelated (Kendall and McDonnell 2012), it is impossible to identification of nitrification depending on relationship between $\delta^{15} \mathrm{~N}_{\mathrm{NO}_{3}^{-}}$and $\delta^{18} \mathrm{O}_{\mathrm{NO}_{3}^{-}}$. However, because two of the three oxygen atoms in $\mathrm{NO}_{3}^{-}$are derived from ambient water, the positive correlation between $\delta^{18} \mathrm{O}_{\mathrm{NO}_{3}^{-}}$and $\delta^{18} \mathrm{O}_{\mathrm{H}_{2} \mathrm{O}}$ is usually used as an indicator of nitrification (Lee et al. 2008). Samples took from TPQN showed clear increase in $\delta^{18} \mathrm{O}_{\mathrm{NO}_{3}^{-}}$along with the increase of $\delta^{18} \mathrm{O}_{\mathrm{H}_{2} \mathrm{O}}$ (Fig. 7a) which illustrated that occurrence of nitrification. TPQN received large amount of municipal sewage and industrial wastewater after entering Puyang City with EC value sharply increased to $5630 \mu \mathrm{S} / \mathrm{cm}$ at TPQN02, and sewage and wastewater are usually rich in ammonia which supplies necessary conditions for nitrification.
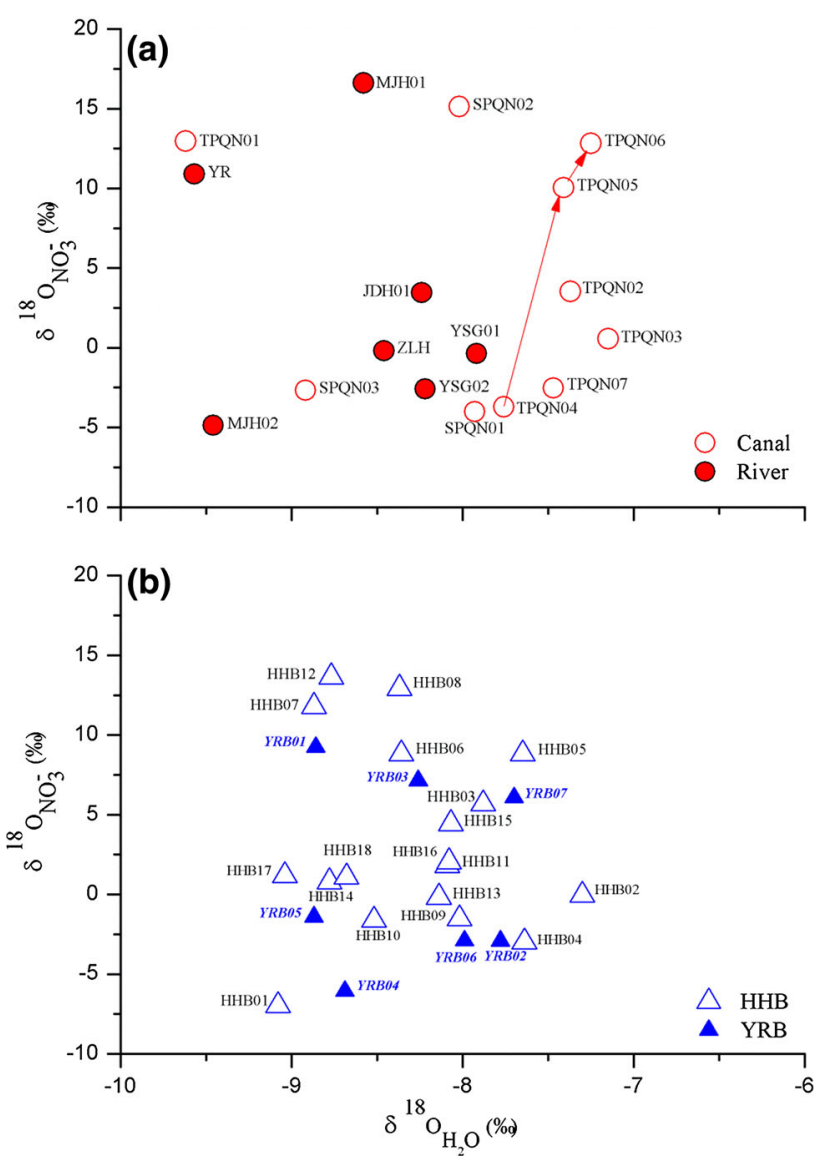

Fig. 7 Plot of $\delta^{18} \mathrm{O}-\mathrm{NO}_{3}^{-}$versus $\delta^{18} \mathrm{O}-\mathrm{H}_{2} \mathrm{O}$ for a surface water samples and $\mathbf{b}$ groundwater samples

\section{Source and fate of nitrate in surface water}

\section{Source of nitrate in rivers}

The Yellow River is the most turbid large river in the world with suspended sediment concentrations average 20$50 \times 10^{3} \mathrm{mg} / \mathrm{L}$ in the middle and lower parts (Zhang et al. 1995). Nitrate concentration of the Yellow River is $25.63 \mathrm{mg} / \mathrm{L}$, which is slightly higher than the analysis result of 13.6, 19.5 and $20.6 \mathrm{mg} / \mathrm{L}$ conducted in August 2003, September 2003 and May 2005 (Chen et al. 2007). According to statistics data, $9.729 \times 10^{9} \mathrm{~m}^{3}$ of the Yellow River water in 2013 was diverted for irrigation, industrial and domestic use in the whole Puyang region which has an area of $4188 \mathrm{~km}^{2}$. Large amount of water derived from the Yellow River will not only contribute to nitrate in surface water, but also probably exert an effect on nitrate in groundwater through vertical infiltration of crop irrigation and lateral seepage of surface water. The $\delta^{15} \mathrm{~N}_{\mathrm{NO}_{3}^{-}}$value in the Yellow River is $+6.890 \%$, which is in consistent with analysis result of $+5.1 \%$ in Gaocun closed to study area conducted in late October 2011 by Liu et al. (2013). The 
$\delta^{18} \mathrm{O}_{\mathrm{NO}_{3}^{-}}$value of the Yellow River is $+10.90 \%$, which is higher than observed value $-1.6 \%$ in Gaocun. This is probably caused by input of high amount of precipitation in wet season, which has higher $\delta^{18} \mathrm{O}_{\mathrm{NO}_{3}^{-}}$(from +52.5 to $+60.9 \%$ ). The $\delta^{15} \mathrm{~N}_{\mathrm{NO}_{3}^{-}}$and $\delta^{18} \mathrm{O}_{\mathrm{NO}_{3}^{-}}$values of the Yellow River fell into the range indicative of soil organic nitrogen. In the middle reaches of the Yellow River, water loss and soil erosion of Quaternary Loess Plateau provides $10 \%$ of the river discharge and $90 \%$ of the river sediment load for the Yellow River (Zhang et al. 1990), which results in large amount of organic nitrogen in sediments and becomes one of the most important nitrate sources in the middle and lower reaches of Yellow River (Zhang et al. 1995). Due to apparent seasonal variation of precipitation and its contribution to surface water, nitrate sources of surface water also present strong differences during dry season from wet season (Liu and Xing 2012). Because unprocessed atmospheric nitrate only accounted for $0-7 \%$ of the total nitrate in the Yellow River based on more accurate $\Delta^{17} \mathrm{O}$ estimation result (Liu et al. 2013), nitrate in the lower reaches of Yellow River in wet season mainly derives from soil organic nitrogen, which is caused by large amount of soil erosion in the Loess Plateau.

Jindi River is one of the most important tributaries in the lower reaches of the Yellow River, which has the slight lower $\delta^{15} \mathrm{~N}_{\mathrm{NO}_{3}^{-}}\left(+2.25 \%\right.$ ) and $\delta^{18} \mathrm{O}_{\mathrm{NO}_{3}^{-}}(+3.46 \%$ o $)$ values and lower nitrate concentration of $7.72 \mathrm{mg} / \mathrm{L}$. It suggests that chemical fertilizer and soil organic nitrogen both may be responsible mainly for nitrate in it, while other sources such as municipal sewage and manure which are usually enriched heavier ${ }^{15} \mathrm{~N}$ and have very limited contributions. MJH01 has the similar $\delta^{15} \mathrm{~N}_{\mathrm{NO}_{3}^{-}}$ value comparing with JDH01, but with extremely high nitrate concentration $(108.76 \mathrm{mg} / \mathrm{L})$ which probably suggests greater contribution of synthetic fertilizer than organic soil nitrogen. In addition, high $\delta^{18} \mathrm{O}_{\mathrm{NO}_{3}^{-}}$ $(+16.61 \%$ o) may illustrate the great effect of nitrate-nitrogen fertilizer. MJH river received large amount of domestic sewage after entering into Nanle County, the main sources for nitrate changed from synthetic nitrogen fertilizer and soil organic nitrogen to manure and septic waste, with the $\delta^{15} \mathrm{~N}_{\mathrm{NO}_{3}^{-}}$increased from $+2.78 \%$ in MJH01 to $+14.09 \%$ at $\mathrm{MJH} 02$, and $\delta^{18} \mathrm{O}_{\mathrm{NO}_{3}^{-}}$decreased from $+16.61 \%$ in $\mathrm{MJH} 01$ to $-4.870 \%$ at $\mathrm{MJH02}$, which are exactly the symbols of manure/sewage contamination and microbial nitrification. Both of ZLH and YSG are located in the lower reaches of MJH, which has the similar isotope composition with $\mathrm{MJH02}$, with $\delta^{15} \mathrm{~N}_{\mathrm{NO}_{3}}$ ranging from +14.74 to $+20.01 \%$, and $\delta^{15} \mathrm{~N}_{\mathrm{NO}_{3}}$ ranging from -0.19 to $-2.58 \%$.
In general, in the wet season nitrate in the Yellow River can be mainly attributed to mineralization of organic matter in sediment. And other rivers usually derived nitrate from synthetic fertilizer in ambient croplands including nitrate-nitrogen fertilizer and ammonia nitrogen fertilizer. While nitrate in rivers located in the downstream of concentrated residential area largely affected by municipal sewage and industrial wastewater.

\section{Source of nitrate in canals}

Rivers and irrigation canals are both as the most important surface water bodies. Different from rivers, water quality of irrigation canals didn't raised much more attention in the past. In fact, in order to facilitate irrigation, irrigation canals were usually established across concentrated farmland which makes them readily receive return flow from ambient croplands with lots of organic manure or synthetic fertilizer. In addition, field investigations found that municipal sewage and industrial wastewater that distributed along the irrigation canals also constitute another constant pollution which further complicated nitrate source discrimination.

All of the irrigation canals derive water from the Yellow River in the southernmost and transport it from the south to the north. Except FPQN is connected with MJH in its lower reaches, SPQN and TPQN are located in the west and east part of study area without direct connections with local rivers. In rainy season, precipitation usually can fully meet crop water demand and it's also the time to carry out watersediment regulation in the upper reaches of the Yellow River; thus, there are usually very limited water remaining in irrigation canals due to reduced or even stopped water diversion from the Yellow River, which make them extremely readily affected by anthropogenic activities compared with rivers. Both of the $\delta^{15} \mathrm{~N}_{\mathrm{NO}_{3}^{-}}$and $\delta^{18} \mathrm{O}_{\mathrm{NO}_{3}^{-}}$ values in canals showed greater variations than rivers (Fig. 6a). In general, SPQN located in agricultural area has the smaller $\delta^{15} \mathrm{~N}_{\mathrm{NO}_{3}^{-}}$value than TPQN which passes through concentrated residential area, and their $\delta^{15} \mathrm{~N}_{\mathrm{NO}_{3}^{-}}$ values didn't show large differences. Along with SPQN canal, nitrate concentration and oxygen isotope in nitrate of SPQN01 and SPQN03 were very similar, which suggested they experienced microbial reactions. The increase of EC and $\mathrm{Cl}^{-}$concentration and decrease of $\delta^{15} \mathrm{~N}_{\mathrm{NO}_{3}^{-}}$value from SPQN01 to SPQN03 illustrated the increased input of chemical fertilizer to nitrate in canals. It is worth noting that sharp rise of $\delta^{18} \mathrm{O}_{\mathrm{NO}_{3}^{-}}$value in SPQN02 and significant lower $\mathrm{T}$ and $\mathrm{pH}$, which probably indicate of point source pollution. In addition, significant decrease in nitrate concentration and increase in its isotopic compositions 
probably illustrated occurrence of denitrification when dissolved oxygen concentration is less than $2 \mathrm{mg} / \mathrm{L}$.

TPQN01, located in the upstream of dense sewage drainage outlets, received rainfall as its main water source during wet season because water diversion usually largely decreased in rainy season when precipitation can fully satisfy crop water demand. It has the depleted $\delta^{18} \mathrm{O}_{\mathrm{H}_{2} \mathrm{O}}$ and $\delta \mathrm{D}_{\mathrm{H}_{2} \mathrm{O}}$ values of -9.62 and $-64.78 \%$ with $\mathrm{EC}$ value of $371 \mu \mathrm{S} / \mathrm{cm}$, which is a further indication of precipitation source (Table 1). However, high nitrate concentration and $\delta^{15} \mathrm{~N}_{\mathrm{NO}_{3}^{-}}$value in TPQN01 suggested that different from relatively single water source, nitrate in TPQN01 possibly was affected by another nitrate sources such as nitrate in remaining water and sediments in canals.

Due to inadequate drainage facilities in the western region of Puyang City, large amount of industrial wastewater and municipal sewage are discharged into TPQN irrigation canal. EC value in site TPQN02 jumped to $5630 \mu \mathrm{S} / \mathrm{cm}$ and gradually fell to $3560 \mu \mathrm{S} / \mathrm{cm}$ at site TPQN05 after around $20 \mathrm{~km}$ of flow path. As discussed before, nitrate isotopic compositions cannot reveal their pollutant sources due to fractionation effect during nitrification. But from the plot of $\mathrm{NO}_{3}^{-} / \mathrm{Cl}^{-}$molar ratio versus $\mathrm{Cl}^{-}$, it can be found that water samples from TPQN irrigation canal clearly fell into the range indicative of municipal inputs which is consistent with field investigation result. Because allocation mechanism of water resources between Henan and Hebei provinces remains obscure, regulation sluice over TPQN canal in the administrative boundary was almost closed all throughout the year. In the downstream of water sluice, EC value of TPQN07 is $1039 \mu \mathrm{S} / \mathrm{cm}$, which is greatly lower than that at TPQN06 but comparable to EC levels in Wei River.

In general, EC values in SPQN (from 792 to $1779 \mu \mathrm{S} / \mathrm{cm}$ ) are obviously smaller than that in TPQN, which is probably because SPQN mainly distributes in agricultural cultivation region while TPQN passes across Puyang City with dense population and well-developed industries. Geographic variations become one of the most important factors that affect nitrate sources for surface water.

\section{Source and fate of nitrate in groundwater}

Compared to surface water, nitrate in groundwater is not readily affected directly by surface sources because of a series of biochemistry reactions occurred in soil and aquifer, but usually is the result of multiple factors including thickness of vadose zone, hydraulic conditions of aquifer and sediment compositions.

Due to big differences of hydraulic conditions and sediment compositions between YRB and HHB, nitrate sources for groundwater in YRB and HHB are different which can be found in nitrate isotopic compositions (Fig. 6b). Groundwater nitrate in YRB is closely related to hydraulic conditions due to shallow water table and variable hydraulic gradients. YRB01 and YRB03 with higher hydraulic gradient had the higher $\delta^{18} \mathrm{O}_{\mathrm{NO}_{3}^{-}}$values $(+9.24$ and $+7.15 \%$ ), while $\delta^{18} \mathrm{O}_{\mathrm{NO}_{3}^{-}}$values of YRB02, YRB04, YRB05 and YRB06 with much lower hydraulic gradient ranged from -6.07 to $-1.40 \%$ (Fig. 6b). This is probably because groundwater with low hydraulic gradients always has a relative small flow velocity and long residence time which helps occurrence of microbial processes. The $\delta^{15} \mathrm{~N}_{\mathrm{NO}_{3}^{-}}$value in YRB01 with groundwater buried depth of $2.15 \mathrm{~m}$ is $+0.30 \%$ indicative of contributions of chemical fertilizer and $\mathrm{NH}_{4}^{+}$in precipitation. With the increase of water table, microbial processes such as denitrification and soil mineralization gradually contribute more to the nitrate in groundwater. The significant correlation between $\delta^{15} \mathrm{~N}_{\mathrm{NO}_{3}^{-}}$and $\delta^{18} \mathrm{O}_{\mathrm{NO}_{3}^{-}}$illustrated that possibility of denitrification in YRB.

Compared to $\delta^{15} \mathrm{~N}_{\mathrm{NO}_{3}^{-}}$of groundwater in YRB, $\delta^{15} \mathrm{~N}_{\mathrm{NO}_{3}^{-}}$ of groundwater in $\mathrm{HHB}$ has a narrow range from +4.13 to $+15.70 \%$, with most of the samples falling into the range indicative of manure and septic waste contamination (Fig. 6b). Groundwater samples took from the confluent area of rivers, $\mathrm{MJH}$ and $\mathrm{ZLH}$, clustered together with very similar $\delta^{15} \mathrm{~N}_{\mathrm{NO}_{3}}$ (from +7.63 to $+9.99 \%$ ) and $\delta^{18} \mathrm{O}_{\mathrm{NO}_{3}^{-}}$values (from -1.62 to $+1.81 \%$ ). The nitrate concentrations in confluent area ranged from 13.85 to $152.63 \mathrm{mg} / \mathrm{L}$ with the average value of $94.80 \mathrm{mg} / \mathrm{L}$, which is close to concentration level of nitrate in MJH01 of $108.76 \mathrm{mg} / \mathrm{L}$. Therefore, nitrate of groundwater in confluent area was probably affected by lateral seepage of surface water and experienced microbial processes during migration. Samples distributed along irrigation canals had slightly higher $\delta^{15} \mathrm{~N}_{\mathrm{NO}_{3}}$ values than the river confluent area. In past 30 years, groundwater in HHB was mainly recharged by infiltration of irrigation water diverted from the Yellow River, which resulted in nitrate in irrigation water continuously entered into groundwater along with water flow. As discussed before, surface irrigation canals derived most of nitrate from municipal inputs; therefore, groundwater recharged by irrigation mainly derived nitrate from municipal sewage and manure. In addition, extensive application of animal manure as basic fertilizer also contributes to nitrate in groundwater.

\section{Conclusions}

In the Yellow River irrigation district, concentrations of $\mathrm{NO}_{3}^{-}$in surface water were lower than in groundwater because of dissolution by large amount of precipitation in 
Table 1 Anion contents, hydrogen and oxygen isotopic compositions of water, and nitrogen and oxygen isotopic compositions of dissolved nitrate in the Yellow River irrigation district

\begin{tabular}{|c|c|c|c|c|c|c|c|c|c|c|c|}
\hline Samples & $\begin{array}{l}\mathrm{EC} \\
(\mu \mathrm{s} / \mathrm{cm})\end{array}$ & $\begin{array}{l}T \\
\left({ }^{\circ} \mathrm{C}\right)\end{array}$ & $\mathrm{pH}$ & $\begin{array}{l}\text { DO } \\
(\mathrm{mg} / \mathrm{L})\end{array}$ & $\begin{array}{l}\mathrm{NO}_{3}^{-} \\
(\mathrm{mg} / \mathrm{L})\end{array}$ & $\begin{array}{l}\mathrm{Cl}^{-} \\
(\mathrm{mg} / \mathrm{L})\end{array}$ & $\begin{array}{l}\mathrm{HCO}_{3}^{-} \\
(\mathrm{mg} / \mathrm{L})\end{array}$ & $\begin{array}{l}\delta^{15} \mathrm{~N}_{\mathrm{NO}_{3}^{-}} \\
(\% o)\end{array}$ & $\begin{array}{l}\delta^{18} \mathrm{O}_{\mathrm{NO}_{3}^{-}} \\
(\% \mathrm{o})\end{array}$ & $\begin{array}{l}\delta^{18} \mathrm{O}_{\mathrm{H}_{2} \mathrm{O}} \\
(\% \text { o })\end{array}$ & $\begin{array}{l}\delta^{2} \mathrm{H}_{\mathrm{H}_{2} \mathrm{O}} \\
(\% 0)\end{array}$ \\
\hline \multicolumn{12}{|c|}{ Irrigation canals } \\
\hline SPQN01 & 792 & 30.5 & 8.11 & 9.39 & 21.59 & 63.0 & 231.3 & 11.427 & -4.012 & -7.93 & -63.23 \\
\hline SPQN02 & 1779 & 29.6 & 7.61 & 1.48 & 2.51 & 387.9 & 204.3 & 11.551 & 15.133 & -8.02 & -61.13 \\
\hline SPQN03 & 1391 & 32.9 & 8.10 & 16.57 & 21.59 & 166.8 & 383.5 & 2.691 & -2.663 & -8.92 & -59.26 \\
\hline TPQN01 & 371 & 32.7 & 7.60 & 4.84 & 38.79 & 22.4 & 117.6 & 12.210 & 12.958 & -9.62 & -64.78 \\
\hline TPQN02 & 5630 & 29.6 & 8.13 & 3.17 & 67.42 & 1106.3 & 521.0 & 11.745 & 3.525 & -7.37 & -58.47 \\
\hline TPQN03 & 4960 & 31.1 & 7.58 & 0.78 & 4.92 & 1011.9 & 687.8 & 5.521 & 0.559 & -7.15 & -52.84 \\
\hline TPQN04 & 3640 & 30.7 & 7.85 & 1.22 & 2.97 & 625.0 & 525.2 & 26.171 & -3.709 & -7.76 & -58.35 \\
\hline TPQN05 & 3560 & 32.5 & 8.04 & 6.38 & 7.05 & 623.6 & 508.5 & 16.757 & 10.037 & -7.41 & -58.18 \\
\hline TPQN06 & 5440 & 31.5 & 7.92 & 11.53 & 5.43 & 1198.8 & 504.4 & 12.208 & 12.824 & -7.25 & -55.71 \\
\hline TPQN07 & 1039 & 30.8 & 7.88 & 8.51 & 16.32 & 116.8 & 183.4 & 13.733 & -2.530 & -7.47 & -59.26 \\
\hline \multicolumn{12}{|c|}{ Natural rivers } \\
\hline YSG01 & 1637 & 31.5 & 8.09 & 5.81 & 60.40 & 194.7 & 408.5 & 14.736 & -0.370 & -7.92 & -56.29 \\
\hline YSG02 & 1664 & 35.0 & 8.02 & 17.40 & 36.69 & 211.4 & 458.5 & 20.000 & -2.579 & -8.22 & -57.12 \\
\hline JDH01 & 935 & 32.7 & 8.05 & 5.99 & 7.72 & 90.2 & 295.1 & 2.252 & 3.458 & -8.24 & -63.32 \\
\hline MJH01 & 1243 & 31.3 & 7.86 & 3.18 & 108.76 & 122.5 & 429.3 & 2.783 & 16.608 & -8.58 & -62.15 \\
\hline MJH02 & 802 & 34.0 & 7.34 & 11.22 & 27.62 & 87.4 & 233.4 & 14.094 & -4.870 & -9.46 & -67.88 \\
\hline YR & 796 & 28.8 & 7.90 & 5.61 & 25.63 & 57.9 & 232.6 & 6.890 & 10.889 & -9.57 & -69.04 \\
\hline ZLH & 643 & 35.7 & 7.50 & 19.42 & 15.79 & 67.8 & 162.6 & 16.480 & -0.187 & -8.46 & -65.21 \\
\hline \multicolumn{12}{|c|}{ Haihe River basin (HHB) } \\
\hline HHB01 & 1185 & 16.5 & 7.97 & 0.94 & 2.07 & 50.5 & 717.8 & 5.065 & -6.977 & -9.08 & -64.86 \\
\hline HHB02 & 2430 & 19.3 & 7.64 & 5.53 & 439.06 & 194.3 & 600.2 & 6.774 & -0.048 & -7.30 & -62.88 \\
\hline HНB03 & 1679 & 18.0 & 8.02 & 6.84 & 1.14 & 180.4 & 704.5 & 12.693 & 5.685 & -7.88 & -59.19 \\
\hline НHB04 & 1392 & 19.3 & 7.93 & 6.01 & 16.68 & 148.0 & 425.2 & 13.417 & -2.978 & -7.64 & -62.32 \\
\hline HHB05 & 1661 & 19.2 & 8.14 & 4.71 & 6.18 & 271.0 & 416.8 & 9.427 & 8.822 & -7.65 & -58.11 \\
\hline HНB06 & 1151 & 17.8 & 7.79 & 3.26 & 1.95 & 33.8 & 777.4 & 9.427 & 8.822 & -8.36 & -62.10 \\
\hline HHB07 & 1347 & 17.2 & 8.22 & 1.84 & 3.47 & 53.9 & 812.8 & 13.106 & 11.790 & -8.87 & -65.33 \\
\hline HНB08 & 2430 & 18.1 & 8.19 & 0.94 & 0.96 & 197.5 & 1104.6 & 10.483 & 12.938 & -8.37 & -60.31 \\
\hline НHB09 & 2630 & 17.7 & 8.09 & 5.75 & 110.52 & 273.2 & 775.3 & 8.974 & -1.536 & -8.02 & -59.32 \\
\hline HHB10 & 3580 & 17.9 & 8.26 & 4.80 & 111.55 & 406.7 & 1029.6 & 9.921 & -1.618 & -8.52 & -62.87 \\
\hline HHB11 & 2114 & 16.8 & 7.70 & 1.48 & 85.44 & 177.1 & 775.3 & 7.981 & 1.813 & -8.09 & -62.73 \\
\hline HHB 12 & 1672 & 19.4 & 7.76 & 2.67 & 7.17 & 71.6 & 679.4 & 10.616 & 13.644 & -8.77 & -59.59 \\
\hline HHB13 & 2370 & 17.2 & 7.77 & 5.02 & 152.63 & 230.9 & 679.4 & 7.631 & -0.184 & -8.14 & -59.09 \\
\hline HHB14 & 4280 & 17.7 & 8.12 & 1.54 & 13.85 & 538.7 & 929.5 & 9.994 & 0.797 & -8.78 & -56.43 \\
\hline HHB 15 & 1662 & 17.5 & 8.01 & 2.62 & 7.46 & 200.0 & 621.1 & 12.730 & 4.440 & -8.07 & -57.05 \\
\hline HHB16 & 1816 & 18.4 & 8.01 & 1.36 & 0.33 & 273.7 & 487.7 & 12.796 & 2.048 & -8.08 & -57.77 \\
\hline HHB17 & 1688 & 19.4 & 7.97 & 2.35 & 41.01 & 173.7 & 479.4 & 15.696 & 1.174 & -9.04 & -56.12 \\
\hline HHB18 & 2179 & 19.3 & 7.94 & 2.10 & 19.50 & 370.0 & 500.2 & 4.127 & 1.089 & -8.68 & -58.49 \\
\hline \multicolumn{12}{|c|}{ Yellow River basin $(Y R B)$} \\
\hline YRB01 & 1378 & 17.6 & 8.21 & 1.12 & 5.06 & 90.4 & 812.8 & 0.298 & 9.241 & -8.86 & -67.12 \\
\hline YRB02 & 1597 & 17.9 & 8.37 & 3.36 & 1.22 & 204.2 & 662.8 & 13.454 & -2.915 & -7.78 & -59.04 \\
\hline YRB03 & 1543 & 16.7 & 8.04 & 3.55 & 0.49 & 74.0 & 687.8 & 15.068 & 7.153 & -8.26 & -60.40 \\
\hline YRB04 & 1740 & 17.5 & 8.45 & 2.74 & 0.45 & 39.5 & 1146.3 & 7.190 & -6.066 & -8.69 & -64.94 \\
\hline YRB05 & 2260 & 18.0 & 7.81 & 3.73 & 26.20 & 418.2 & 552.3 & 15.655 & -1.400 & -8.87 & -66.32 \\
\hline YRB06 & 1325 & 16.7 & 8.07 & 6.23 & 1.73 & 61.8 & 760.7 & 14.105 & -2.896 & -7.99 & -60.62 \\
\hline YRB07 & 3070 & 19.2 & 7.95 & 2.57 & 2.36 & 591.0 & 687.8 & 26.193 & 6.083 & -7.70 & -58.61 \\
\hline
\end{tabular}


wet season. Approximately $17.7 \%$ of the surface water samples and $20.0 \%$ of the groundwater samples had exceeded nitrate concentrations over WHO drinking water standard.

Combined use of hydrogeochemical data, nitrate-nitrogen and oxygen isotopic information, hydrogen and oxygen isotopic compositions in water molecules is a useful method to identify nitrate source and transformation processes. There is no mixing process or one single microbial process that is responsible for the shifts in nitrogen and oxygen isotopic values in surface water or groundwater.

In this study, nitrate in the Yellow River is mainly derived from soil organic nitrogen due to serious soil and water losses of the Loess Plateau in its upper reaches. Nitrate in other important medium and small tributaries is mainly affected by anthropogenic activities other than natural precipitation and soil organic matter in sediments. Of which, MJH01 and JDH distributed in agricultural areas derive the most of nitrate from agricultural activities such as application of synthetic fertilizer and pesticide, and MJH02 and YSG located in the downstream of concentrated residential area are usually heavily influenced by industrial wastewater and municipal sewage. The isotopic compositions of nitrate suggested that nitrate sources for irrigation canals mainly depended on its ambient environment. SPQN in agricultural area received large amount of return flow of irrigation and rainfall from ambient farmland in wet season, with dissolved synthetic and manure fertilizers as its main source and domestic sewage discharge from scattered villages as minor contributor. Nitrate in TPQN canal that passing through the biggest concentrated residential zone Puyang city can be attributed to drainage of local municipal sewage and industrial wastewater, and high correlation between $\delta^{18} \mathrm{O}_{\mathrm{NO}_{3}^{-}}$and $\delta^{18} \mathrm{O}_{\mathrm{H}_{2} \mathrm{O}}$ and enrichment of lighter ${ }^{14} \mathrm{~N}$ in nitrate along with water flow indicated occurrence of nitrification processes.

Different from surface water, nitrate in groundwater is not only affected by surface sources, but also closely related to hydraulic conditions. Due to great differences of hydraulic conditions in YRB and HHB, main sources for nitrate in groundwater are different. In YRB, nitrate in groundwater with extremely shallow water tables mainly influenced by vertical seepage of atmospheric nitrate and fertilizer application in surface soil. Besides, in places with relatively high water table and low hydraulic gradients, denitrification probably took place due to long residence time in aquifer and anaerobic environment which can be supported by the close relationship between $\delta^{18} \mathrm{O}_{\mathrm{NO}_{3}^{-}}$and $\delta^{15} \mathrm{~N}_{\mathrm{NO}_{3}^{-}}$. With the decline of water table, groundwater nitrate reflects long-term accumulative effect with samples took from rivers confluent area mainly deriving nitrate from river water and others distributing along irrigation canals had higher $\delta^{15} \mathrm{~N}_{\mathrm{NO}_{3}^{-}}$values indicative of manure and septic waste contamination.

Acknowledgments The research is financially supported by the National Basic Research Program (973 Program) of China (No. 2010CB428805). Special thanks to Yali Wu and Fei Liu for assistance in field sampling and Dr. Hongmei Bu for instructions in preparation work during nitrate isotopes laboratory analysis.

\section{References}

Altman SJ, Parizek RR (1995) Dilution of nonpoint-source nitrate in groundwater. J Environ Qual 24:707-718

Andersson KK, Hooper $\mathrm{AB}(1983) \mathrm{O}_{2}$ and $\mathrm{H}_{2} \mathrm{O}$ are each the source of one $\mathrm{O}$ in $\mathrm{NO}_{2}{ }^{-}$produced from NH3 by Nitrosomonas: $15 \mathrm{~N}-$ NMR evidence. FEBS Lett 164:236-240

Anthonisen AC, Loehr RC, Prakasam TBS, Srinath EG (1976) Inhibition of nitrification by ammonia and nitrous acid. $\mathrm{J}$ (Water Poll Control Fed) 48:835-852

Appelo CAJ, Postma D (2005) Geochemistry, groundwater and pollution, 2nd edn. Taylor \& Francis, Abingdon

Battaglin WA, Kendall C, Chang CC, Silva SR, Campbell D (2001) Chemical and isotopic evidence of nitrogen transformation in the Mississippi River, 1997-98. Hydrol Process 15:1285-1300

Böhlke J, Denver J (1995) Combined use of groundwater dating, chemical, and isotopic analyses to resolve the history and fate of nitrate contamination in two agricultural watersheds, Atlantic coastal plain, Maryland. Water Resour Res 31:2319-2339

Böttcher J, Strebel O, Voerkelius S, Schmidt HL (1990) Using isotope fractionation of nitrate-nitrogen and nitrate-oxygen for evaluation of microbial denitrification in a sandy aquifer. J Hydrol 114:413-424

Campbell DH, Kendall C, Chang CCY, Silva SR, Tonnessen KA (2002) Pathways for nitrate release from an alpine watershed: determination using $\delta^{15} \mathrm{~N}$ and $\delta^{18} \mathrm{O}$. Water Resour Res 38:1011-10-19

Chen J, Tang C, Sakura Y, Yu J, Fukushima Y (2005) Nitrate pollution from agriculture in different hydrogeological zones of the regional groundwater flow system in the North China Plain. Hydrogeol J 13:481-492

Chen J, Taniguchi M, Liu G, Miyaoka K, S-i Onodera, Tokunaga T, Fukushima Y (2007) Nitrate pollution of groundwater in the Yellow River delta, China. Hydrogeol J 15:1605-1614

DiSpirito A, Hooper A (1986) Oxygen exchange between nitrate molecules during nitrite oxidation by Nitrobacter. J Biol Chem 261:10534-10537

Durka W, Schulze E-D, Gebauer G, Voerkeliust S (1994) Effects of forest decline on uptake and leaching of deposited nitrate determined from $15 \mathrm{~N}$ and $18 \mathrm{O}$ measurements. Nature 372:765-767

Fan AM, Steinberg VE (1996) Health implications of nitrate and nitrite in drinking water: an update on methemoglobinemia occurrence and reproductive and developmental toxicity. Regul Toxicol Pharmacol 23:35-43

Feigin A, Shearer G, Kohl DH, Commoner B (1974) The amount and nitrogen-15 content of nitrate in soil profiles from two central Illinois fields in a corn-soybean rotation. Soil Sci Soc Am J 38:465-471

Fewtrell L (2004) Drinking-water nitrate, methemoglobinemia, and global burden of disease: a discussion. Environ Health Perspect 112(14):1371-1374

GB/T 5750-2006. Standard examination methods for drinking water [S] 
Goss MJ, Barry DAJ, Rudolph DL (1998) Contamination in Ontario farmstead domestic wells and its association with agriculture: 1. Results from drinking water wells. J Contam Hydrol 32:267-293

Granger J, Sigman DM, Needoba JA, Harrison PJ (2004) Coupled nitrogen and oxygen isotope fractionation of nitrate during assimilation by cultures of marine phytoplankton. Limnol Oceanogr 49:1763-1773

Gu B, Ge Y, Chang SX, Luo W, Chang J (2013) Nitrate in groundwater of China: sources and driving forces. Glob Environ Change 23:1112-1121

Heaton THE (1986) Isotopic studies of nitrogen pollution in the hydrosphere and atmosphere: a review. Chem Geol Isot Geosci Sect 59:87-102

Hollocher T, Tate M, Nicholas D (1981) Oxidation of ammonia by Nitrosomonas europaea. Definite ${ }^{18} \mathrm{O}$-tracer evidence that hydroxylamine formation involves a monooxygenase. J Biol Chem 256:10834-10836

Kendall C, Aravena R (2000) Nitrate isotopes in groundwater systems. In: Peter G. Cook, Andrew L. Herczeg (eds) Environmental tracers in subsurface hydrology. Kluwer academic, Norwell, pp 261-298

Kendall C, McDonnell JJ (2012) Isotope tracers in catchment hydrology. Elsevier, Amsterdam

Kendall C, Campbell DH, Burns DA, Shanley JB, Silva SR, Chang CC (1995) Tracing sources of nitrate in snowmelt runoff using the oxygen and nitrogen isotopic compositions of nitrate. IAHS Publ Ser Proc Rep Int Assoc Hydrol Sci 228:339-348

Kendall C, Elliott EM, Wankel SD (2008) Tracing anthropogenic inputs of nitrogen to ecosystems. In: Stable isotopes in ecology and environmental science. Blackwell Publishing Ltd, Oxford, UK, pp 375-449

Kohl DH, Shearer GB, Commoner B (1971) Fertilizer nitrogen: contribution to nitrate in surface water in a corn belt watershed. Science 174:1331-1334

Lee K-S, Bong Y-S, Lee D, Kim Y, Kim K (2008) Tracing the sources of nitrate in the Han River watershed in Korea, using $\delta^{15} \mathrm{~N}-\mathrm{NO}_{3}^{-}$and $\delta^{18} \mathrm{O}-\mathrm{NO}_{3}^{-}$values. Sci Total Environ 395:117-124

Li K, Song L (2004) Lowering of groundwater levels and countermeasures of their prevention and control in the city of Puyang. Hydrogeol Eng Geol 31:79-81

Liu W, Xing M (2012) Isotopic indicators of carbon and nitrogen cycles in river catchments during soil erosion in the arid Loess Plateau of China. Chem Geol 296-297:66-72

Liu C-Q, Li S-L, Lang Y-C, Xiao H-Y (2006) Using $\delta^{15} \mathrm{~N}$ - and $\delta^{18} \mathrm{O}-$ values to identify nitrate sources in karst ground water, Guiyang, Southwest China. Environ Sci Technol 40:6928-6933

Liu J, Gao GC, Zhu T, Guo N, Tong X, Fan H (2010) Climatic change and influence on agricultural production in Puyang from 1960 to 2008 (In Chinese). Chin Agric Sci Bull 26:357-363

Liu T, Wang F, Michalski G, Xia X, Liu S (2013) Using 15N, 17O, and $18 \mathrm{O}$ to determine nitrate sources in the Yellow River, China. Environ Sci Technol 47:13412-13421
Lu H, Jing W, Zhao J, Liu X, Huang Z (2014) Characteristics of the temporal variation in temperature and precipitation in China's lower Yellow River region. Adv Meteorol 2014:1-15

Mariotti A, Landreau A, Simon B (1988) 15 N isotope biogeochemistry and natural denitrification process in groundwater: application to the chalk aquifer of northern France. Geochim Cosmochim Acta 52:1869-1878

McIsaac GF, David MB, Gertner GZ, Goolsby DA (2001) Eutrophication: Nitrate flux in the Mississippi River. Nature 414:166-167

Mengis M, Schif S, Harris M, English M, Aravena R, Elgood R, MacLean A (1999) Multiple geochemical and isotopic approaches for assessing ground water $\mathrm{NO}_{3}^{-}$elimination in a riparian zone. Groundwater 37:448-457

Min J-H, Yun S-T, Kim K, Kim H-S, Hahn J, Lee K-S (2002) Nitrate contamination of alluvial groundwaters in the Nakdong River basin, Korea. Geosci J 6:35-46

Ren H, Tang D (1998) Water price and regulation and control of water resources in the irrigated areas at the lower reaches of delivering water from the Yellow River (in Chinese). Grograph Res 17:48-55

Robinson D (2001) $\delta 15 \mathrm{~N}$ as an integrator of the nitrogen cycle. Trends Ecol Evol 16:153-162

Shen Y, Lei H, Yang D, Kanae S (2011) Effects of agricultural activities on nitrate contamination of groundwater in a Yellow River irrigated region. IAHS Publ 348:73-80

Silva S, Kendall C, Wilkison D, Ziegler A, Chang C, Avanzino R (2000) A new method for collection of nitrate from fresh water and the analysis of nitrogen and oxygen isotope ratios. J Hydrol 228:22-36

Wankel SD, Kendall C, Francis CA, Paytan A (2006) Nitrogen sources and cycling in the San Francisco Bay Estuary: a nitrate dual isotopic composition approach. Limnol Oceanogr $51: 1654-1664$

WHO (2011) Guidelines for drinking-water quality, vol 1, 4th edn. World Health Organization, Geneva

Xue D et al (2009) Present limitations and future prospects of stable isotope methods for nitrate source identification in surface- and groundwater. Water Res 43:1159-1170

Zhang J, Wen Huang W, Chong Shi M (1990) Huanghe (Yellow River) and its estuary: sediment origin, transport and deposition. J Hydrol 120:203-223

Zhang J, Huang W, Letolle R, Jusserand C (1995) Major element chemistry of the Huanghe (Yellow River), China-weathering processes and chemical fluxes. J Hydrol 168:173-203

Zhang Y, Li F, Zhang Q, Li J, Liu Q (2014) Tracing nitrate pollution sources and transformation in surface- and ground-waters using environmental isotopes. Sci Total Environ 490:213-222. doi:10. 1016/j.scitotenv.2014.05.004 